\title{
Multiconcept Methods to Enhance Photovoltaic System Efficiency
}

\author{
D. T. Cotfas $(\mathbb{D})$ and P. A. Cotfas \\ Electrical Engineering and Computer Science Faculty, Transilvania University of Brasov, Romania \\ Correspondence should be addressed to D. T. Cotfas; dtcotfas@unitbv.ro
}

Received 18 April 2019; Revised 16 October 2019; Accepted 6 November 2019; Published 25 November 2019

Academic Editor: Jegadesan Subbiah

Copyright $\odot 2019$ D. T. Cotfas and P. A. Cotfas. This is an open access article distributed under the Creative Commons Attribution License, which permits unrestricted use, distribution, and reproduction in any medium, provided the original work is properly cited.

\begin{abstract}
The main goal of this paper is to review the most important methods previously developed to enhance the efficiency and increase the lifetime of photovoltaic panels. The methods to increase the solar radiation incident on photovoltaic panels, as well as the cooling and the maximum power point tracker methods, are concisely presented in this paper. The pros and cons analysis reveals that the methods to enhance the power generated by the photovoltaic panels are strongly dependent on geographical location, climatic conditions, and the materials used. This review paper is also of interest for engineers who attempt to identify the most adequate solutions to maximize the energy output of photovoltaic systems for each location.
\end{abstract}

\section{Introduction}

The electricity demand has greatly increased in recent years due to economy and population growth in developing countries, a gradual rise in comfort levels in well-developed countries, the demand for more goods and services, and the increase in the number of electric vehicles for public transportation and electric cars [1]. India's energy demand will increase the global one with $30 \%$ and only a part of the Chinese industry will increase the electricity demand with $20 \%$ by 2040, according to the International Energy Agency [1]. The increase in electricity demand leads to rising levels of pollution. This can be prevented if the electricity is produced by using renewable energy.

The photovoltaic systems (PV) which convert the solar energy in electric energy are the most important systems from the renewable energy ones. The added solar PV capacity worldwide in 2017 was $98 \mathrm{GW}$, and the total installed PV capacity by the end of 2017 was 402 GW [2].

The electric power generated by the photovoltaic panels can be increased if their efficiency is enhanced. Moreover, if PV lifetime is also increased, the total amount of the electricity generated is further grown.
The efficiency of the most important photovoltaic panels varies from $10 \%$ to $38 \%$ if the photovoltaic cells and panels are measured under Standard Test Conditions (STC) - air mass (AM) 1.5 , temperature $25^{\circ} \mathrm{C}$, and irradiance $1000 \mathrm{~W} / \mathrm{m}^{2}$. The comparison between the most efficient photovoltaic cells and PV panels is presented in Table 1. The efficiency of the PV panels is smaller than the PV cells used for its construction. In the case of aSi, the difference is very small, while for Perovskite, it is high, this being explained by the fact that the technology is still young. The Perovskite cell is a promising candidate for a very good efficiency as well as the multijunction cells. Thus, one way to increase efficiency is to find new proper materials to make better photovoltaic cells.

In order to ensure the necessary energy amount, the maximum power $\left(P_{\max }\right)$ generated by the photovoltaic panels has to increase. This can be achieved by the production process following the research results and through extrinsic methods which are the topic of this paper because the panels' users can bring improvements. For the first type issue, an example is to maximize the active area of the photovoltaic cells. The Maxeon third generation photovoltaic cells have fingers and bus bars, which have been moved from the front face on the back one; thus, all contacts are on the back of the cell. Thus, the 
TABLe 1: Efficiency of the PV cells and panels measured under STC [3].

\begin{tabular}{|c|c|c|c|c|c|c|c|}
\hline \multirow[b]{2}{*}{ Material } & \multicolumn{7}{|c|}{ Efficiency (\%) } \\
\hline & $\mathrm{mSi}$ & a-Si/nc-Si & GaAs & CIGS & Perovskite & CdTe & InGaP/GaAs/InGaAs \\
\hline PV cell & $26.7[4]$ & $12.7[5]$ & $29.1[6]$ & $22.9[7]$ & $20.9[8]$ & $21.0[9]$ & $37.9[10]$ \\
\hline PV panel & $24.4[4]$ & $12.3[11]$ & $25.1[12]$ & $19.2[13]$ & $11.6[14]$ & $18.6[15]$ & $31.2[16]$ \\
\hline
\end{tabular}

entire front area is active. The energy generated from the Maxeon photovoltaic system is higher by over 30\% than other photovoltaic systems for the same area used during the last 25 years [17].

For this study, it is important to identify, describe, and discuss pros and cons of the methods and their results to enhance the performance of existing photovoltaic panels in work environment. The parameters of the photovoltaic panels are given after their testing in STC conditions, which are very rarely reached in real conditions. It is important to add something to obtain the maximum power specified by the producer or to exceed this amount.

The maximum power generated by the photovoltaic panels increases with the solar radiation which falls on them. This issue can be solved by using sun tracker systems [1820], which reflect the solar radiation on photovoltaic panels $[21,22]$ and solar concentrating systems [23]. All these solutions cause other problems which have to be solved in order to obtain real improvements. One of the most important problems is that the temperature of the photovoltaic panels increases with the irradiance growth, and in concentration systems, the acceptable functioning temperature for photovoltaic cells is very easily exceeded especially for high concentration rates $[24,25]$. The maximum power generated by the monocrystalline silicon cell decreases with around $0.45 \% /{ }^{\circ} \mathrm{C}$ [24], and the lifetime also decreases [26]. The cooling methods, passive as well as active ones, are used to reduce the temperature of the photovoltaic cell. The uniformity of the temperature on the photovoltaic panel surface is very important for the PV to work properly, and the cooling methods must ensure this. Another problem that arises is whether the cooling method is sustainable from the economic perspective. Does the additional energy generated due to the cooling system used cover its extra cost? The extra lifetime of the photovoltaic panels, ensured by the cooling system, is important to be taken into consideration, also from the economic point of view. Therefore, the cooling system is absolutely necessary for the photovoltaic cells in concentrated light systems.

It is also very important to use all the power which can be generated by the photovoltaic panels to enhance the performance of the system, and thus, the use of the maximum power point tracking (MPPT) becomes a necessity.

Other factors which can have negative consequences for the PV panel energy output are dust, shade, humidity, wind speed, direction, and tilt angle [25].

The paper is structured in five sections, as follows: the methods to increase the solar radiation which falls on the PV panels are presented in Section 2. In Section 3, the methods to increase the power generated by the PV panels using cooling are discussed. Section 4 provides in a concise manner the maximum power point tracking methods. The last section is dedicated to discussions and conclusions.

\section{Methods to Increase the Solar Radiation Which Falls on the PV Panels}

2.1. Sun Tracker Systems. Theoretically, the solar radiation falling on the PV panels increases by $41 \%$ when the dual axis sun tracker is used [18], but the increase in generated energy varies between $10 \%$ and $45 \%$ in comparison with fixed systems $[19,20]$. The energy consumed by the PV system to follow the sun when the tracking system is used varies between $2 \%$ and $5 \%$ from the generated energy. If the processes for the sun tracker are not optimized, this can be even higher [20]. The sun tracker systems are more complex than the fixed systems, and the maintenance is more expensive. The sun tracker is absolutely necessary for the concentrated light systems.

The main types of the sun trackers and the gain in power in comparison with the fixed PV system are presented in Table 2.

The power gain when the sun tracker is used is strongly dependent on the type of trackers, the location [29], seasons, months, day types $[27,34]$, and the PV panel technologies. The most widely known classification of the sun trackers is in function of the axis number: with single axis and dual axis (Figure 1). For example, for the dual-axis sun tracker based on MPPT, the gain is $28.8 \%$ in winter, $33.6 \%$ in spring, $43.6 \%$ in summer, and $38.3 \%$ in winter [35].

The power gain depends on the PV panel technologies. The gain for four PV types when a dual axis with algorithm is used is $17 \%$ for amorphous silicon panels, $18 \%$ for monocrystalline silicon panels, 5\% for polycrystalline silicon panels, and 20\% for CIS panels [37]. The power gain also depends on the seasons of the year and implicitly on the month. The experimental results for the gain obtained using a dual-axis sun tracker active system, in Patras, Greece, are $31.11 \%$ for April, $32.78 \%$ for May, 36.85\% for June, and $34.2 \%$ for July (Figure 2) [38].

2.2. Reflective Systems. The maximum power generated by the photovoltaic panels can be increased if the reflected solar radiation falls on the photovoltaic panels. This can be obtained in natural-passive reflectance and artificial-active reflectance modes.

2.2.1. Passive Reflectance. The solar radiation is reflected by the surface. The albedo provides the information about the solar radiation amount which is reflected by each type of surface. The albedo for different types of surfaces is presented in Table 3 [39-41]. 
TABLE 2: Sun tracker types and gain.

\begin{tabular}{|c|c|c|c|}
\hline Type & Description & Gain in power & Ref. \\
\hline \multirow{6}{*}{ Single axis } & $\begin{array}{l}\text { (1) The rotation is on E-W direction, and on N-S, the panel is tilted at } 30^{\circ} \text {. } \\
\text { It is an active tracker, based on closed-loop (two photodiodes are used). }\end{array}$ & $\begin{array}{l}15.3 \% \text { - cloudy day } \\
16.2 \% \text { - partially clear } \\
\text { day } \\
23.2 \% \text { - clear day }\end{array}$ & [27] \\
\hline & $\begin{array}{l}\text { (2) The rotation is on N-S direction. It is an active tracker, based on } \\
\text { closed-loop (algorithm). The system movement is electromechanical. }\end{array}$ & $20 \%$ & [28] \\
\hline & $\begin{array}{l}\text { (3) The rotation is on E-W direction, and it is an active tracker with algorithms. } \\
\text { The fixed system is near earth for site A, is one of the } 90 \text { sun trackers but } \\
\text { deactivated for site } \mathrm{B} \text {, and is tilted at } 30^{\circ} \text { for site C. }\end{array}$ & $\begin{array}{l}37.7 \% \text { site } \mathrm{A} \\
30.4 \% \text { site } \mathrm{B} \\
31.5 \% \text { site } \mathrm{C}\end{array}$ & [29] \\
\hline & $\begin{array}{l}\text { (4) The rotation is on E-W direction, and it is an active tracker based } \\
\text { on closed-loop (sensors). }\end{array}$ & $45 \%$ & [30] \\
\hline & $\begin{array}{l}\text { (5) The rotation is on N-S direction, and it is a passive tracker based on } \\
\text { two bimetallic strips. }\end{array}$ & $23 \%$ & [31] \\
\hline & (6) Tracker with three positions (fixed angles) for morning, noon, and afternoon. & $24.5 \%$ & [32] \\
\hline \multirow{4}{*}{ Dual axis } & $\begin{array}{l}\text { (1) It is an active tracker with a tracking algorithm. The system movement is } \\
\text { electromechanical. }\end{array}$ & $42.6 \%$ & [33] \\
\hline & (2) Equatorial sun tracker. It is an active tracker with sensors. & $\begin{array}{l}108 \mathrm{Whr} / \mathrm{m}^{2} \text { - cloudy } \\
\text { day } \\
603 \mathrm{Whr} / \mathrm{m}^{2} \text { - clear day }\end{array}$ & {$[34]$} \\
\hline & (3) It is an active tracker based on MPPT. & $37.1 \%$ & [35] \\
\hline & (4) It is an active tracker based on an algorithm. & $24.59 \%$ & [36] \\
\hline
\end{tabular}

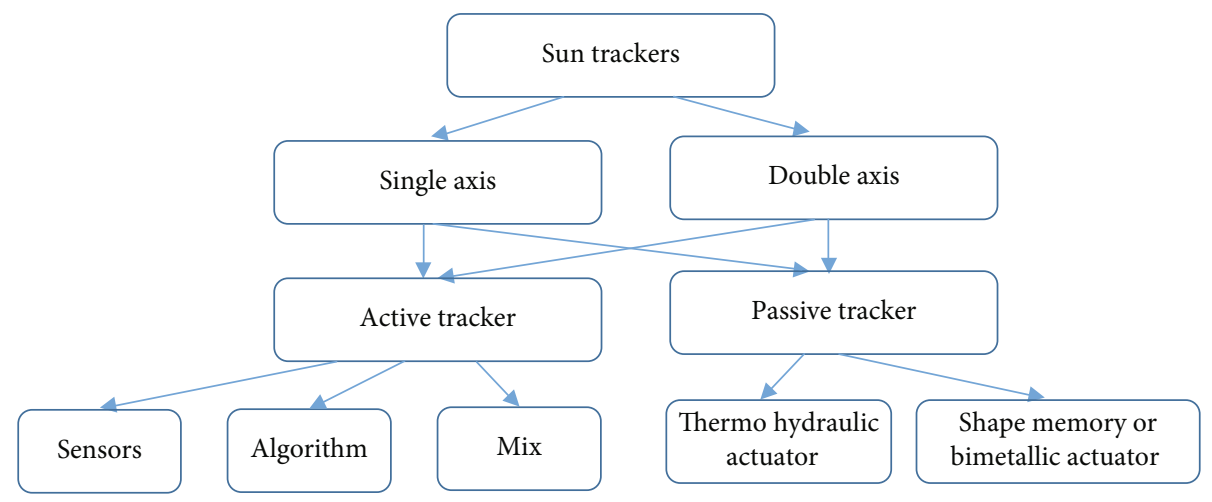

FIGURE 1: Classification of sun trackers.

The additional irradiance which falls on the photovoltaic panels depends on the albedo, the shape of the reflective surface, and the tilt angle of the PV panels.

There are some studies on the increasing maximum power generated by the photovoltaic panels using the passive reflectance. The photovoltaic panels which are mounted on a flat large roof or large flat land can receive additional solar radiation by reflection. The roofs are generally covered with waterproof materials which have a small reflection, such as bituminous membrane (BM) and cement slabs (Table 3). Nowadays, there are waterproof materials with high reflection, such as white tiles or white waterproof materials, which have an albedo above $70 \%$. Also, the roof and the land in winter can be covered with snow which has the albedo of up to $92 \%$.

D.T. Cotfas and P.A. Cotfas proposed a simple method to increase the power generated by the PV panels [21].
The expanded polystyrene was used to simulate the white waterproof material or snow. The albedo of the expanded polystyrene (EP) is over $80 \%$. Two "twin" photovoltaic panels are used to study the effect of the reflected solar radiation, one being placed on the expanded polystyrene to receive the solar reflected radiation from EP and another to receive the solar reflected radiation from the bituminous membrane [21]. The comparison of the maximum power generated by PV panels with solar reflected radiation from the bituminous membrane BMR and from the expanded polystyrene EPR is presented in Figure 3. The comparison is made for different solar global radiation values from $100 \mathrm{~W} / \mathrm{m}^{2}$ to $1000 \mathrm{~W} / \mathrm{m}^{2}$, measured with a pyranometer placed in the same plane with the PV panels on a clear day. The gain in percentages for the maximum power of the PV panel with EPR varies from $8 \%$ at $100 \mathrm{~W} / \mathrm{m}^{2}$ irradiance to $17 \%$ at $1000 \mathrm{~W} / \mathrm{m}^{2}$ irradiance. The gain in power, function of the irradiance, is linear (Figure 4). 


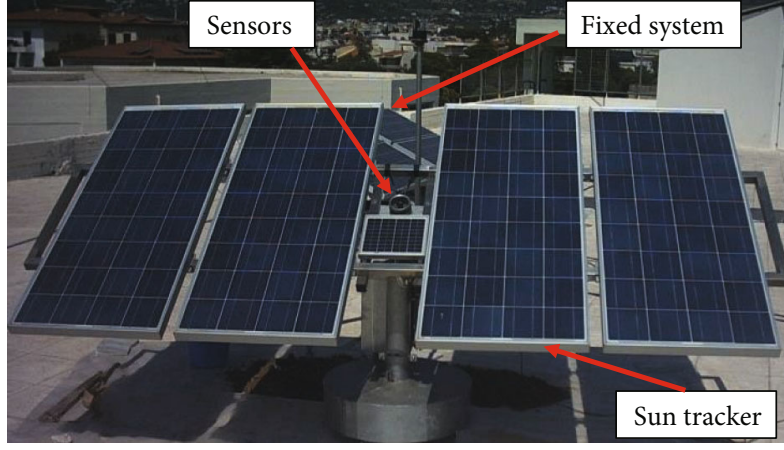

Figure 2: Dual-axis sun tracker active and fixed system, Patras, Greece.

TABLE 3: Albedo values.

\begin{tabular}{lc}
\hline Surface & Albedo (\%) \\
\hline Dry soil (dark) & 9 \\
Bituminous membrane & 13 \\
Cement slabs & 15 \\
Green grass & 23 \\
Concrete & 25 \\
Concrete (milky) & 46 \\
Old snow & $45-50$ \\
White tiles & 71 \\
Aluminum foil & 75 \\
White painted concrete & $60-80$ \\
Expanded polystyrene & 83 \\
Fresh snow & $90-92$ \\
\hline
\end{tabular}

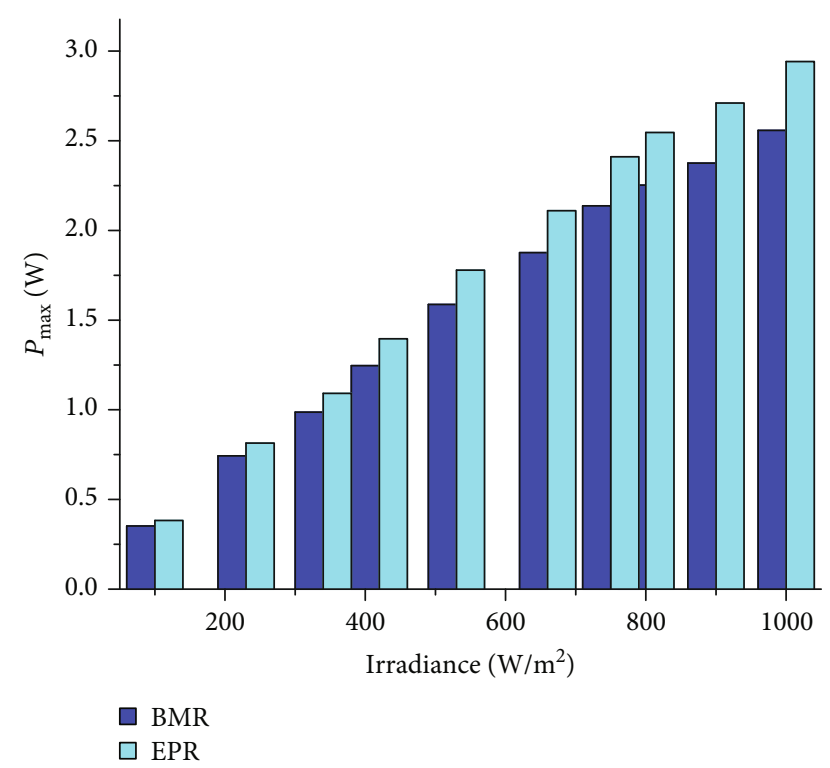

Figure 3: $P_{\max }$ generated by the two PV panels.

Meyta and Savrasov have obtained an increase by $7.3 \%$ in the current generated by the monocrystalline photovoltaic minipanel when it is placed on the ground covered with snow [40].

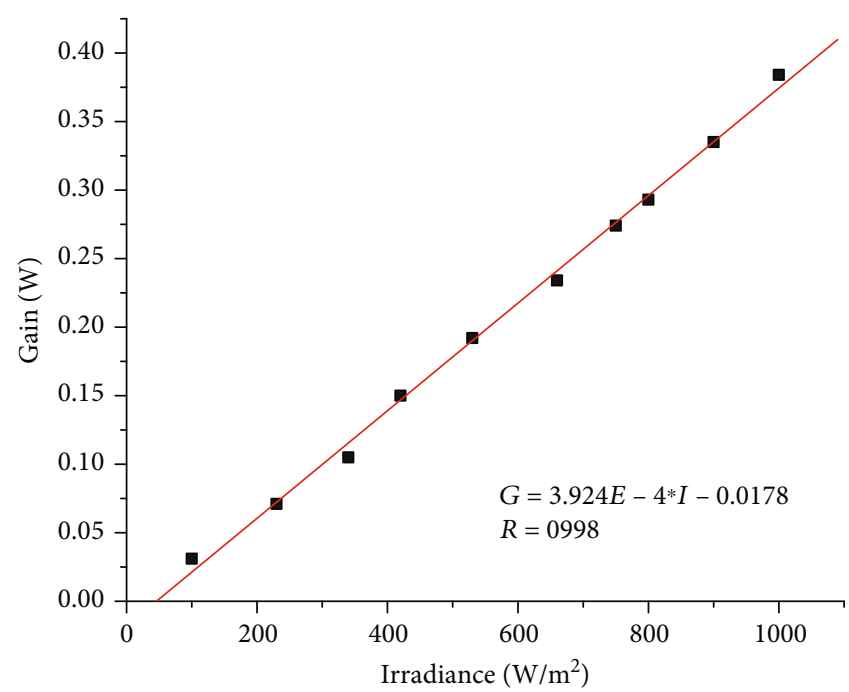

FIgure 4: Gain in $P_{\max }$ for PV panel in EPR case.

The passive reflectance plays a very important role in radiation gain for the bifacial photovoltaic panels. The gain in power of the bifacial $\mathrm{PV}$ panels in comparison with monofacial PV panels is reported to be between $13 \%$ and $35 \%$ for sunny days and between $40 \%$ and $70 \%$ for cloudy days. The variation is determined by the height at which the photovoltaic panels are mounted from the ground $[41,42]$. The height influences the amount of the solar radiation reflected which falls mainly on the back of the panels and also on their front. Chiodetti et al. calculated the influence of the albedo for the power generated by the rear side of the bifacial PV panels [43]. They obtained that the contribution of the albedo is of $68.1 \%$ for $20 \%$ albedo, $81 \%$ for $40 \%$ albedo, and $86.5 \%$ for $60 \%$ albedo.

2.2.2. Active Reflectance. The reflected solar radiation which falls on the photovoltaic panels can be artificially increased by using different methods. One method is to use mirrors (glass mirrors or anodized aluminum), but reflective surfaces, such as aluminum foil or zinc tiles, can be used in order to reduce the system price. The concentration rate for these methods is very low, up to maximum 3 times.

These systems can use from one mirror to four mirrors [44]. The most used systems are those using two mirrors, and they are called V-troughs [45-49].

The V-trough systems generally have to be used with sun tracker systems. The systems with one or two mirrors (Figure 5) can be used with or without the sun tracker [50]. The inclination angle of the mirrors is very important to maximize the gain. Kostić et al. calculated the optimal inclination angle of the mirrors towards the PV panel. The optimal angle was found $66^{\circ}$ [51].

Arshad et al. measured the gain in power for the system with mirrors without the sun tracker. The measured power of the PV monocrystalline silicon panel without mirrors is $24.84 \mathrm{~W}$. They obtained $28.84 \mathrm{~W}$ for the panel with one mirror, $31.25 \mathrm{~W}$ for the system with two mirrors, and 36.93 for the system with three mirrors [44]. The gain for the last system in comparison with the first is $48.7 \%$. 


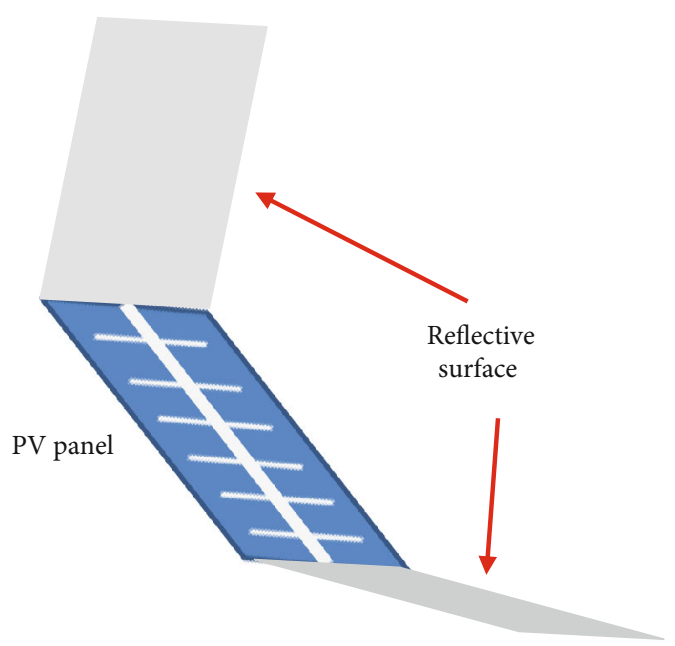

Figure 5: PV panel with mirror system.

The gain in power when the V-trough systems is used is concisely presented in Table 4.

2.3. Refractive Systems. The Fresnel lens is the best candidate and the most used for refractive concentration light (Figure 6). The rate of concentration can vary from low concentration, of up to 10 suns, to high concentration, of up to 2000 suns [23]. The polycarbonate Fresnel lens is widely used due to its lower cost and greater toughness in comparison to methyl methacrylate. The latter is more resistant to scratch [53] and has only longitudinal chromatic aberration [23]. The spherical and chromatic aberrations decrease the optical efficiency at the high concentration rate [54]. There are some solutions to reduce the chromatic aberrations and increase the performance of the Fresnel lens, such as using a hybrid refractive/diffractive design and using two different optical materials [54, 55]. Zhou et al. obtained a 98.5\% transmittance [56] by using antifogging and antireflective coating for the Fresnel lens. Another problem of the Fresnel lens is the angular acceptance which is acceptable for low concentration rates and low for high concentration rates. The solution proposed by Akisawa et al. is a dome-shaped lens [57].

\section{PV Panel Cooling Methods}

The maximum power generated by the PV panels is strongly influenced by their temperature. The temperature growth has a negative influence on the electrical energy produced by photovoltaic cells. The percentage of the maximum power decreasing if the temperature rises by one degree for four photovoltaic cells is presented in Figure 7 [24]. The most widespread PV panels, monocrystalline and polycrystalline silicon, have the highest maximum power temperature coefficient. In semiarid and arid regions, the temperature of PV panels reaches more than $80^{\circ} \mathrm{C}$ [58].

All methods presented in the previous section of the paper increase the solar radiation received by PV panels which leads to rise in their temperature and lifetime reduction. Thus, continuous efforts to improve or find new methods to cool PV panels are necessary.
The main cooling methods of the photovoltaic panels are presented in Figure 8.

3.1. Air Cooling. The natural air flow is the most common method for cooling the PV panels due to its simplicity, no extra materials being needed, and the cost being relatively low. However, cooling of photovoltaic panels can be improved if on the back of PV panels metallic materials with fins are mounted to ensure a very good air circulation [5961]. By using natural air flow between the building vertical walls and PV system mounted on them, the temperature of the photovoltaic panels can be maintained at less than $40^{\circ} \mathrm{C}$ [61] which is smaller with almost $20^{\circ} \mathrm{C}$ than the average.

The forced air circulation is an active method to cool the photovoltaic panels. There are more methods to force the air circulation, such as open channel beneath, steel plate with an air channel underneath, and array of air ducts underneath the PV panels with optimum fins $[62,63]$. Teo et al. using the array ducts significantly decrease the temperature of the photovoltaic panels, and their efficiency increases between 12 and $14 \%[62]$.

3.2. Water Cooling. The cooling with water of the photovoltaic panels has been studied since the end of the 1960s, when the first hybrid PVT panels were build (photovoltaic panel and solar thermal collector), and this technology underwent a rapid development after the 1990s. Nowadays, there is a multitude of types of PVT, such as with natural and forced water circulation, using nonconcentrated and concentrated sunlight, glazing and without glazing, with and without absorber plate, and other types [64].

These hybrid panels can produce electric energy and thermal energy in almost the same space. He et al. studied a PVT which consists of a monocrystalline silicon panel placed on the absorber plate with a water pipe attached beneath. The water circulation is a natural one. The efficiency of the photovoltaic panel is comparable with the one that does not have a solar collector, and for the solar collector, the efficiency is around $40 \%$. The efficiency of the hybrid system is much higher than that of a conventional system [65]. Yang and Yin found that the maximum power of the PV panel in hybrid systems increases with $23 \%$ in comparison with PV panel alone, and the solar thermal collector generates $661 \mathrm{~W} / \mathrm{m}^{2}$ [66]. Xu et al. proposed a concentrated PVT system. The Fresnel lenses and an optical prism are used to concentrate the sunlight up to 1090 suns. The efficiency of the photovoltaic cells is $28 \%$, and the thermal efficiency is $60 \%$ [67].

The temperature of the photovoltaic panels can be reduced using the water which flows on the panels or is sprayed on them. Krauter proposed a method to cool the photovoltaic cell using the water flow on the surface of the panel. The results show that the efficiency of the PV panels increases with $10.3 \%$. The water flow, $4.41 / \mathrm{min}$, is achieved using a pump and 12 nozzles placed on the top of the PV panel assuring the distribution of the water. The photovoltaic cell temperature decreases up to $22^{\circ} \mathrm{C}$ which increases the lifetime of the PV panels. The water film reduces the reflection by $2-3.6 \%$. The gain of the system is $9 \%$ if the pump 
TABLE 4: V-trough system.

\begin{tabular}{|c|c|c|c|}
\hline Description & Gain $(\%)$ & $\begin{array}{c}\text { Rate of } \\
\text { concentration }\end{array}$ & Reference \\
\hline $\begin{array}{l}\text { Ya'acob et al. made a comparative study using three monocrystalline silicon } \\
\text { photovoltaic systems: fix (F), dual-axis sun tracker (DST), and V-trough system } \\
\text { with sun tracker (V); the rated power of all three systems is } 1 \mathrm{~kW}\end{array}$ & $\begin{array}{l}\text { DST to } \mathrm{F} \text { is } 9.4 \\
\mathrm{~V} \text { to } \mathrm{DST} \text { is } 23.4 \\
\mathrm{~V} \text { to } \mathrm{F} \text { is } 32.8\end{array}$ & 2 & [48] \\
\hline $\mathrm{Hu}$ and Yachi proposed an innovative $\mathrm{V}$ system with tracker for each mirror & $\begin{array}{l}70 \text { to the panel } \\
\text { without mirror }\end{array}$ & - & [49] \\
\hline $\begin{array}{l}\text { Tina and Scandura compared the power generated by two photovoltaic systems: } \\
\text { one is a single-axis tracking system (azimuth) (SA) and the second is a dual-axis } \\
\text { tracking system with mirrors (M) }\end{array}$ & $\mathrm{M}$ to $\mathrm{SA}$ is 34 & 1.81 & [51] \\
\hline $\begin{array}{l}\text { Solanki et al. proposed a system which consists of } 6 \text { monocrystalline silicon panels, } \\
\text { each of them being placed in a V system }\end{array}$ & $\begin{array}{l}7.7 \text { to the panels } \\
\text { without mirrors }\end{array}$ & 2 & [46] \\
\hline $\begin{array}{l}\text { Maiti et al. study two } 10 \mathrm{~W} \text { photovoltaic panels placed on V-trough. One } \\
\text { PV panel is cooled with PCM material, and the second is not. A manual sun } \\
\text { tracker on East-West direction is used. The panels are tilted at } 18.9^{\circ} \text { to the horizontal, } \\
\text { which is the optimum angle }\end{array}$ & $\begin{array}{l}55 \text { to the panels } \\
\text { without mirrors } \\
\text { and PCM }\end{array}$ & 2 & [47] \\
\hline $\begin{array}{l}\text { Singh et al. compared the generated power of two systems: one is V-trough system } \\
\text { and the other is compound parabolic concentrator (CPC). Four monocrystalline } \\
\text { silicon photovoltaic cell series connected are used for each concentrator }\end{array}$ & $\begin{array}{l}\mathrm{V} \text { to } \mathrm{CPC} \text { is } 17.2 \\
\text { at the specific tilt } \\
\text { angle } 30^{\circ}\end{array}$ & 2.2 & [52] \\
\hline
\end{tabular}

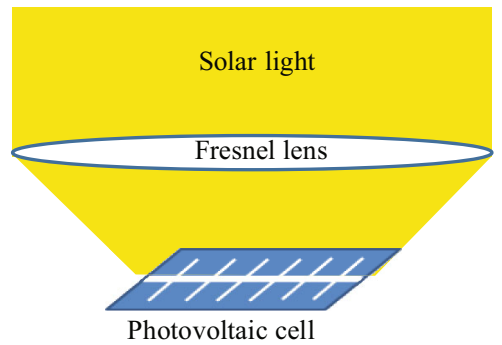

FIgURE 6: Fresnel light concentration system.

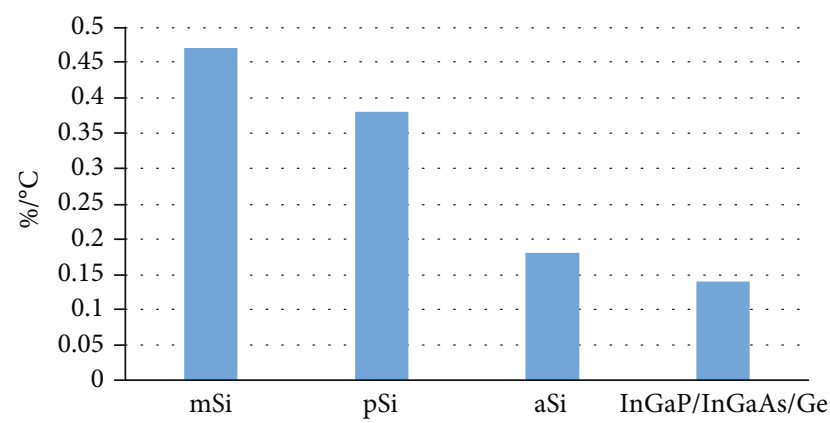

FIgURE 7: The decrease percentage in maximum power for different types of photovoltaic cells.

consumption is taken into account [68]. Moharram et al. developed a water spray system to cool the photovoltaic panels [69]. The system consists of six PV panels, a water tank, a centrifugal pump, 120 water nozzles for spraying water, and a system to recover the water. The temperature of the photovoltaic cells is decreased at $35^{\circ} \mathrm{C}$ when the spraying system is used [69]. Abdolzadeh and Ameri also studied the cooling system based on the water spray technique. The working temperature of the $\mathrm{PV}$ panels is $37.5^{\circ} \mathrm{C}$ when the ambient temperature is $33^{\circ} \mathrm{C}$ and the flow is $50 \mathrm{l} / \mathrm{h}[70]$.
Clot et al. studied the behavior of the PV single crystalline silicon panel submerged in water [71]. The temperature of the PV panel which operates in natural conditions is around $70^{\circ} \mathrm{C}$, but the temperature decreases at $30^{\circ} \mathrm{C}$ if it is submerged at $4 \mathrm{~cm}$. The efficiency of the panel submerged increases with $11 \%$. This increase is limited by water absorption. If the PV panel is submerged at $40 \mathrm{~cm}$, the efficiency decreases with $23 \%$.

The PV floating is another possibility to reduce the temperature of the photovoltaic panels. Cazzaniga et al. [72] described the PV floating plant which works in low rate concentrated light; the photovoltaic panels have been cooled using water sprinklers. Sacramento et al. used two polycrystalline silicon panels to compare their behavior when one is ground mounted and the other is water floating [73]. The efficiency of the water floating PV panel is higher than that for the other PV panel with 12.5\%.

Water with different nanoparticles is successfully used to reduce the temperature of the photovoltaic cells and to increase the performance of the photovoltaic thermal hybrid systems [74, 75]. Several nanoparticles such as Boehmite (AlOOH- $\left.x \mathrm{H}_{2} \mathrm{O}\right)$, Aluminum oxide $\left(\mathrm{Al}_{2} \mathrm{O}_{3}\right)$, Zinc Oxide $(\mathrm{ZnO})$ and Titanium Oxide $\left(\mathrm{TiO}_{2}\right)$, Magnetite $\left(\mathrm{Fe}_{3} \mathrm{O}_{4}\right)$, Silicon carbide $(\mathrm{SiC})$, and Copper Oxide $(\mathrm{CuO})$ are used at different weight fractions.

Karami and Rahimi used water-based Boehmite with $0.01 \mathrm{wt} \%$ to cool the photovoltaic panels, and the gain in efficiency is $27 \%$ [74]. Hussien et al. used $\mathrm{Al}_{2} \mathrm{O}_{3}$-water nanofluid with concentration ratio $0.3 \%$ for improving the performance of the hybrid $\mathrm{PV} / \mathrm{T}$ panel. The tests are performed at $1000 \mathrm{~W} / \mathrm{m}^{2}$ and mass flow rate of $0.2 \mathrm{~L} / \mathrm{s}$ for $24 \mathrm{~min}$. The temperature of the photovoltaic panel decreases from almost $79^{\circ} \mathrm{C}$ to $35^{\circ} \mathrm{C}$. The efficiency of the PV panel increases from $8 \%$ without nanofluid to $12 \%$, with it, which means a $50 \%$ growth [76]. The photovoltaic panel illuminated at $917 \mathrm{~W} / \mathrm{m}^{2}$ is cooled using the water, $\mathrm{TiO}_{2} /$ water, $\mathrm{ZnO} /$ water, and $\mathrm{Al}_{2} \mathrm{O}_{3}$ /water, and the concentration ratio 


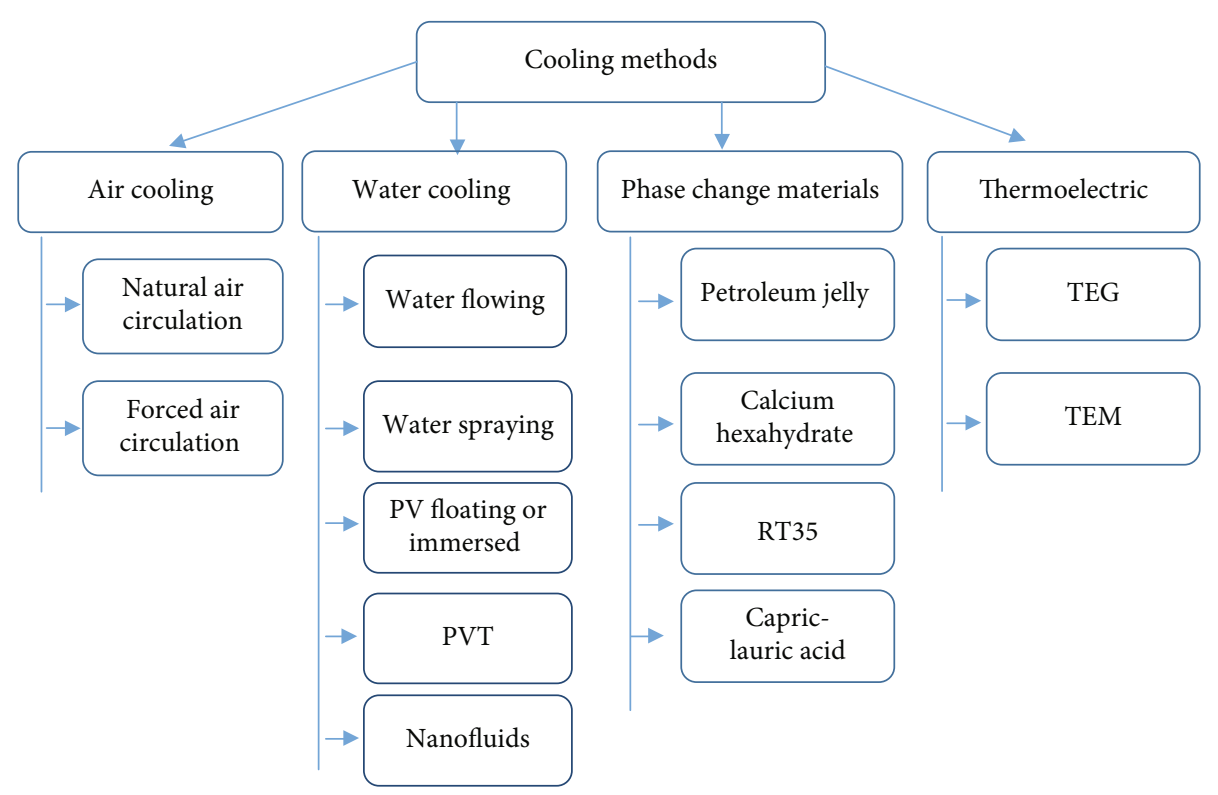

FIGURE 8: The main cooling methods.

was $0.2 \%$. The best enhancement in electrical efficiency was found for $\mathrm{Al}_{2} \mathrm{O}_{3}$ /water $6.36 \%$, and the lowest was for water $5.48 \%$ [77]. Rostami et al. used simultaneous nanofluids and ultrasound to cool the photovoltaic panels. The study took into account variation of the nanoparticle concentration from $0.01 \%$ to $0.8 \%$ and the flow rate from $0.4 \mathrm{~m}^{3} / \mathrm{h}$ to $12.5 \mathrm{~m}^{3} / \mathrm{h}$, and the level of illumination is $1000 \mathrm{~W} / \mathrm{m}^{2}$. The experiment takes 50 minutes. The PV temperature is highly influenced by the flow rate and the concentration rate of the nanoparticles. For $0.8 \%$ concentration rate, the PV temperature decreases from $49^{\circ} \mathrm{C}$ to $24^{\circ} \mathrm{C}$, when the flow rate increases from $0.4 \mathrm{~m}^{3} / \mathrm{h}$ to $12.5 \mathrm{~m}^{3} / \mathrm{h}$, and from $36^{\circ} \mathrm{C}$ to $24^{\circ} \mathrm{C}$, when the concentration rate varies from $0.01 \%$ to $0.8 \%$ at $12.5 \mathrm{~m}^{3} / \mathrm{h}$ flow rate [75].

3.3. PCM. The phase change materials (PCM) have the properties to absorb the excess heat and maintain the PV panels at constant and uniform temperature [78]. There are different PCM materials able to reduce the temperature of the PV panels and to ensure a homogenous distribution of the heat on all photovoltaic panel surface, some of them being noted in Figure 4. Hasan et al., using different PCM materials, obtained a temperature reduction for $\mathrm{PV}$ panels ranging between $10^{\circ} \mathrm{C}$ and $18^{\circ} \mathrm{C}$ [79]. Biwole et al., using PCM materials, could maintain the PV panel temperature under $40^{\circ} \mathrm{C}$ for $80 \mathrm{~min}$ at $1000 \mathrm{~W} / \mathrm{m}^{2}$ irradiance [80]. Indartono et al. improved the efficiency of the roof integrated photovoltaic panels $(10 \mathrm{~W})$ with $21.6 \%$ and with $6 \%$ for the stand-alone panel using PCM (petroleum jelly material) [81]. The temperature of the PV panels can be reduced with $21^{\circ} \mathrm{C}$ for Pakistan and $10^{\circ} \mathrm{C}$ for Ireland when salt hydrate is used [82].

Al-Waeli et al. tested and compared three PV/T systems: one with water, the second with water and PCM, and the third with PCM and nano-SiC-water nanofluid. The results show that the third system has the best performance. The efficiency varies from $13.7 \%$ for PCM and nanofluid and $11.4 \%$ for PCM and water to $8.5 \%$ for water. The electric power generated varies from $81.3 \mathrm{~W}$ (first system) to 111.3 W (third system) [83]. Sardarabadi et al. found that the gain in electricity is higher than $13 \%$ when PCM/nanofluids are used in PV/T panels [84].

3.4. Thermoelectric. The thermoelectric generator (TEG) has been considered a promising part of the PV-TEG hybrid system since the early 2000s. The thermoelectric module can be used to extract a part of the heat of the PV panels and convert it into electric energy based on Seebeck effect. This device can be used to cool the PV panels by consuming the electric energy, based on Peltier effect.

Benghanem et al. cooled the PV panels from the semiand arid regions using one TEG for each panel. The necessary energy to power the TEGs is generated by an additional photovoltaic panel [58]. Cotfas et al. used TEG to build a PVTEG-STC hybrid system and to study it in natural sunlight conditions [85]. The temperature of the photovoltaic cell was reduced with $19^{\circ} \mathrm{C}$, and the power generated increased with $11 \%$. The temperature distribution of the photovoltaic cell shows a very small variation of the heat which has a positive effect on the lifetime of the photovoltaic cells (Figure 9).

Mahmoudinezhad et al. studied the behavior under low concentration of the hybrid system which consists of $\mathrm{GaInP} /$ GaInAs/Ge multijunction photovoltaic cell and $\mathrm{Bi}_{2} \mathrm{Te}_{3}$ thermoelectric generator [86]. The temperature of the multijunction photovoltaic cell increases only up to $120^{\circ} \mathrm{C}$ at 39 suns due to the heat extracted by the thermoelectric generator. Kil et al. determined a gain about 3\% for the power generated by a PV cell used in the hybrid system in comparison with the PV cell alone for a concentrated rate of 50 suns [87].

\section{MPPT Methods}

In order to make maximum use of the output of the PV panels, the DC load has to intersect the current voltage characteristic in the maximum power point. In real operation 


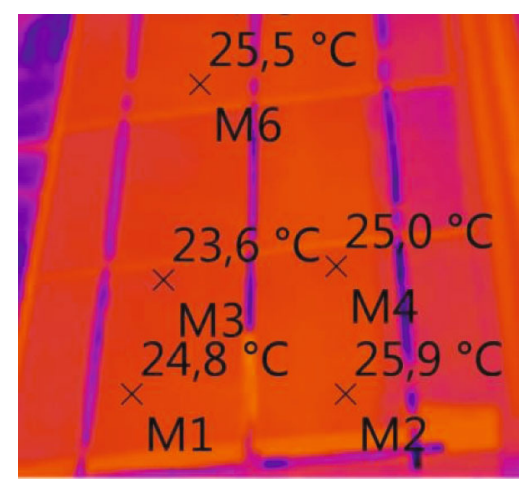

FIgURE 9: The temperature distribution [85].

conditions, this rarely happens due to the load mismatch, the variation of the solar radiation, and temperature. This problem can be overcome by using DC/DC or DC/AC converter with MPP controller [88].

A lot of MPPT methods are being developed, each of them with its own applications and limitations $[89,90]$. They depend on whether the PV panels are used in stand-alone or grid connected systems. A classification of the main MPPT methods is presented in Figure 10.

Karami et al. give some criteria to choose the best MPPT technique for an application such as the following [88].

Implementation: some methods are very simply implemented, for example, the constant voltage; others are more complex, such the methods based on artificial intelligence. For implementation, it is also important that the irradiation and temperature are uniform. The success of the MPPT depends on whether there is shadow or not on the PV panels.

Sensors: the number of sensors must be limited, but sufficient; there are in general four sensors for temperature, solar radiance, voltage, and current. Using simple methods, such as constant voltage or constant current, the number can be reduced at one.

Efficiency: there are methods which have a simple value and methods which allow oscillations around the maximum power point. The losses can become important and can influence the costs.

Cost: cost depends on the complexity of the circuit and method [88].

\section{Discussion and Conclusions}

The performance of the photovoltaic panels can be enhanced if the solar radiation falling on them is increased, the photovoltaic panels are cooled, and smart electronic circuits are used.

The important issue for increasing the irradiance on the photovoltaic panels through sun trackers, active reflectance, and concentration systems is that these systems use mobile parts and the temperature of the photovoltaic panel increases when more solar radiation falls on it. Therefore, the systems are more complex, and questions appear which refer to the additional cost, the energy consumption to move the system, maintenance, the losses in case the system does not work properly or is broken, and which the gain in produced energy is.

The answers for these issues are the following:

The gain: it depends on the sun tracker system type, for single axis the gain is $10-25 \%$ and $25-45 \%$ for double axis; geographical location where the PV system is placed; technology; and materials used for photovoltaic panels. Table 5 comparatively presents the annual energy generated by the $1 \mathrm{~kW}$ PV plant with fixed panels and the $1 \mathrm{~kW}$ PV plant with the dual-axis sun tracker. Three technologies are considered, such as $\mathrm{mSi}$, CIS, and CdTe, and four locations. The gain between the annual energy generated by PV plants placed in Kaunas and Marbella is also calculated. Data used for this comparison is obtained from the Photovoltaic Geographical Information System [91]. The gain can be improved by reflections especially in the morning and in the evening especially in case of dual-axis sun trackers.

Energy consumption: it is $3.5 \%$ in average from the total energy generated, if the sun tracker process is optimized, if not, it can be over $5 \%$. It also depends on the speed and accuracy of the positioning.

Losses: they depend on the problems which appear. The worst case is when the PV system remains blocked for optimum position towards East or West. In this case, the losses are over 95\% from the energy generated per day. In the case of concentration systems, the losses depend on the accuracy of the sun trackers due to the fact that their performance is a function of the acceptance angle, which plays a very important role.

Costs: it is an important factor which must be taken into account when considering whether to implement the sun tracker system or not. It depends on the type of the sun tracker systems, as the cost to produce $1 \mathrm{kWp}$ varies from $\$ 600$ to $\$ 1900$ for dual axis and varies from $\$ 135$ to $\$ 930$ for single axis. The variation appears due to the producers, the components, and the accuracy. Singh et al. assert that the cost for PV fixed photovoltaic panels varies between $\$ 2$ and $\$ 2.4 /$ watt. The supplementary cost for single-axis systems is around $\$ 1.17 /$ watt for dual axis systems, and it is $\$ 0.36 /$ watt comparatively for single axis [19].

Maintenance: it has to be made regularly in order to avoid losses. It is a factor which increases the costs of the PV systems.

In case of fixed photovoltaic systems, it is very important to choose the tilt angle and orientation (azimuth) of the system. The optimum choice of both leads to an increase in generated energy, due to the growth in incident solar radiation and self-cleaning. The fixed PV panel grid connected has to be mounted at the optimum annual tilt angle, because the yearly energy must be maximized. Rhodes et al. et al. calculated for Austin, USA, the optimal annual tilt angle and the azimuth angle, which are $28^{\circ}$ and $188^{\circ}$, respectively [92].

The calculation of the tilt angle for stand-alone applications, such as home systems or solar garden lamps, has to consider other factors, among which the most important is the solar radiation in critical periods of the year. Cotfas et al. et al. developed a prototype for intelligent solar garden lamps in the Steinel project [93]. The critical period for such devices is from October to March. By analyzing the solar radiation for 


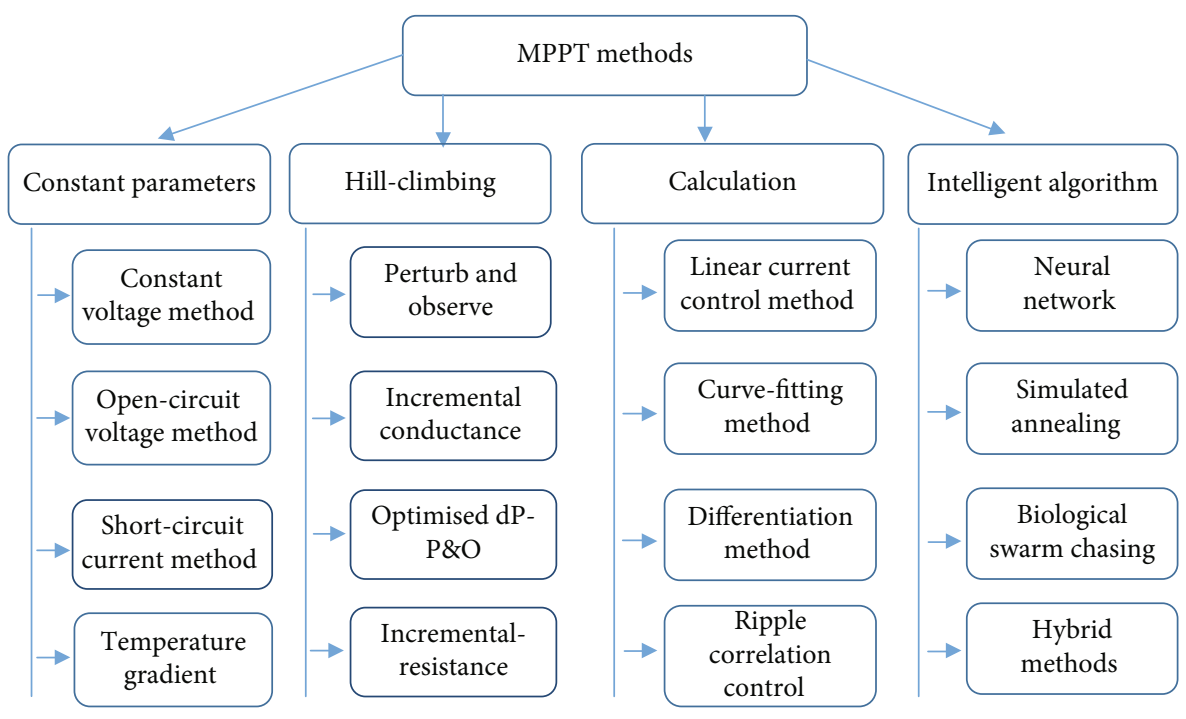

FIGURE 10: The main MPPT methods.

TABLE 5: Comparison of annual energy generated by $1 \mathrm{~kW}$ PV plant.

\begin{tabular}{|c|c|c|c|c|c|c|c|c|c|c|c|}
\hline \multirow{3}{*}{ Location } & \multirow{3}{*}{ Geographical coordinates } & \multirow{3}{*}{ Optimal angle } & \multicolumn{9}{|c|}{ Annual energy generated $(\mathrm{kW})$} \\
\hline & & & \multicolumn{3}{|c|}{$\mathrm{mSi}$} & \multicolumn{3}{|c|}{ CIS } & \multicolumn{3}{|c|}{ CdTe } \\
\hline & & & Fix & DST & Gain (\%) & Fix & DST & Gain (\%) & Fix & DST & Gain (\%) \\
\hline Heraklion, Greece & $\begin{array}{l}\text { Lat. } 35^{\circ} 34^{\prime} \\
\text { Lon. } 25^{\circ} 13^{\prime}\end{array}$ & $28^{\circ}$ & 1650 & 2330 & 41.2 & 1630 & 2290 & 40.4 & 1680 & 2390 & 42.3 \\
\hline Brasov, Romania & $\begin{array}{l}\text { Lat. } 45^{\circ} 65^{\prime} \\
\text { Lon. } 25^{\circ} 61^{\prime}\end{array}$ & $36^{\circ}$ & 1130 & 1470 & 30.1 & 1100 & 1430 & 30 & 1130 & 1490 & 31.8 \\
\hline Kaunas, Lithuania & $\begin{array}{l}\text { Lat. } 54^{\circ} 89^{\prime} \\
\text { Lon. } 23^{\circ} 90^{\prime}\end{array}$ & $38^{\circ}$ & 930 & 1230 & 32.2 & 909 & 1200 & 32 & 918 & 1230 & 33.9 \\
\hline Marbella, Spain & $\begin{array}{l}\text { Lat. } 36^{\circ} 50^{\prime} \\
\text { Lon. }-4^{\circ} 88^{\prime}\end{array}$ & $32^{\circ}$ & 1720 & 2430 & 41.3 & 1690 & 2390 & 41.4 & 1760 & 2510 & 42.6 \\
\hline \multirow{2}{*}{\multicolumn{2}{|c|}{ Gain between Kaunas and Marbella }} & $(\mathrm{kW})$ & 790 & 1200 & & 781 & 1190 & & 842 & 1280 & \\
\hline & & $\%$ & 84.5 & 97.5 & & 85.9 & 99.2 & & 91.7 & 104 & \\
\hline
\end{tabular}

these months, it was concluded that the best solution for the optimum angle was $55^{\circ}$. This solution is validated through experiments, where three small photovoltaic panels, monocrystalline, polycrystalline and amorphous silicon are measured at different angles. The best solution of the solar garden lamp is the monocrystalline photovoltaic panels. The difference between the consumed energy and the energy generated by the photovoltaic panel is negative for all six critical months if the panel is horizontal and for four months (November-February) if the panel is tilted at the optimum annual angle and is positive or zero if the panel is tilted at $55^{\circ}$. Moreover, the chosen tilt angle has the following advantages: generated maximum energy in months with problems in terms of solar radiation, the additional radiation by reflection is incident on the PV panel; improvement of self-cleaning; and temperature reduction for the summer months.

Quesada et al. proposed a strategy for sun tracker system function of the weather: in case of clear sky or only partly sunny, the sun tracker has to work normally; for cloudy days, the sun tracker must be positioned with the PV panels horizontally; and for snowy days, the PV panels have to be at the optimum angle [94].

A method proposed by paper authors to reduce energy consumption for sun tracker systems is to move the position of the system discretely, not continuously, using a mathematical algorithm, for example, once per hour. The first position on the East-West axis is at $7.5^{\circ}$ westwards from the optimal position at sunrise time. The temperature of the PV panels in this case is lower than that for the PV panels directly oriented towards the sun, which leads to the increase of generated power from the temperature point of view. This increase can partially compensate for the losses due to the positioning mismatch between the PV panels for certain periods of time. This method cannot be used for sun tracker systems used for concentrated PV systems, where the PV panels must be permanently oriented directly towards the sun (Figure 11). 


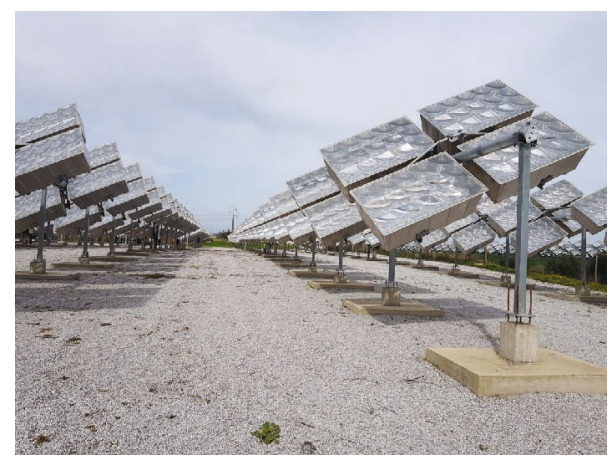

Figure 11: Concentration PV plan Evora, Portugal.

The sun trackers increase the solar incident radiation, but the temperature of the photovoltaic panels also increases. There are studies on this for different types of sun trackers or technologies $[43,95]$. Ya'acob et al. concluded that the maximum difference between the average daily temperature PV fixed panel and PV panels mounted on a dual-axis sun tracker is $3.8^{\circ} \mathrm{C}$, and between a fixed one and a $\mathrm{V}$-trough concentrator, it is $6.11^{\circ} \mathrm{C}$. These differences are higher (more than $15^{\circ} \mathrm{C}$ ) in the morning and evening because the mobile PV panels received more solar radiation.

There are some issues which have to be analyzed when the cooling is used to decrease the temperature of the photovoltaic panels among which the temperature distribution, the extra costs, the location, and the sustainability.

Temperature distribution: uniform temperature distribution on the photovoltaic panels is a key parameter to maximize the power generated by the photovoltaic panels and to increase their lifetime. The nonuniform temperature distribution has as effect growth in the photovoltaic cell temperature, increase in series resistance, fill factor decrease, and maximum power reduction [78]. There are several methods which assure the uniform cooling of the PV panel: direct immersion, phase change material, heat sinks, jet impingement, thermoelectric generators, and microchannels [78, 85]. Bahaidarah shows that if impingement cooling is used instead of the rectangular channel heat exchanger, the temperature nonuniformity is reduced from an average of $3.55^{\circ} \mathrm{C}$ to $1.81^{\circ} \mathrm{C}[96]$.

Costs: Baloch et al. calculated that the cost of the uncooled $\mathrm{PV}$ system is 282.9 whereas for cooled, it is 328.9. Leveled cost of energy (LCE) is calculated to be $1.95(€ / \mathrm{kWh})$ for an uncooled PV system and $1.57(€ / \mathrm{kW} \mathrm{h})$ for cooled [97].

Location: the energy generated by the PV system is dependent on the location. The temperature of the PV system depends on the location; in arid areas, the PV temperature can exceed $85^{\circ} \mathrm{C}$. The cooling system must be more efficient for these areas. Another problem is which type can be successfully used. For arid areas, thermoelectric generators prove to be a suitable choice.

The extracted heat can be converted in thermal or electric energy by using cooling methods, such as PVT or PV-TEG, and the energy generated by the PV panels due to their cooling can increase with around 7.5\% [24]. The electrical and thermal efficiencies of nonconcentrated PVT systems are in the range of $10-12 \%$ and $50-70 \%$, respectively. In case of the submerging method to cool the PV panel, the optimum depth varies from 2 to $4 \mathrm{~cm}$. The disadvantages for this method are that the efficiency of the PV panels decreases over time due to the ionized water and in the cloudy days the generated power is lower than that for ground PV panels.

The multiple PCM (multiple melting points) could be a very good solution for cooling and for homogenous heat distribution. PCM with a low melting point $\left(25^{\circ} \mathrm{C}\right)$ can reduce the PV panel temperature more than PCM with a high melting point (over than $30^{\circ} \mathrm{C}$ ), but for short periods, and hot spots can appear on the PV panel surface. The disadvantages of the PCM are that the absorptive capabilities of material degrade over time and they do not have the same efficiency worldwide. They are more efficient in hot regions than in cold regions.

Although there are plenty of MPPT methods, two of them are most frequently used, Perturb and Observe (P\&O) and incremental conductance (IC). Recently, new methods have been developed using algorithms from the field of artificial intelligence.

The methods from the constant parameter family are the simplest ones to implement, very fast but unstable. In case of the open circuit voltage method, the maximum voltage $V_{\text {MPP }}$ is calculated by multiplying $V_{\mathrm{oc}}$ with $k_{\mathrm{oc}}$, the range of $k_{\mathrm{oc}}$ being 0.73-0.8, 076 for monocrystalline silicon PV panel. The accuracy of the method depends of the choice of $k_{\mathrm{oc}}$. The short circuit method is analog with the open circuit voltage method. In this case, the maximum current is obtained by multiplying the short circuit current with $k_{\mathrm{sc}}$. The value of $k_{\mathrm{sc}}$ varies between 0.85 and 0.92 , for polycrystalline silicon photovoltaic panels being 0.85 . The $\mathrm{P} \& \mathrm{O}$ and IC methods are net superior to open circuit voltage and short circuit current methods for the majority of irradiance levels. However, the open circuit voltage method performs better at low solar radiation than the $\mathrm{P} \& \mathrm{O}$ and IC methods. To improve the MPPT efficiency, the open circuit voltage method can be combined with one of the two Hill climb methods obtaining a MPPT hybrid method, which can perform with high efficiency for all irradiance levels.

MPPT methods, which use algorithms from artificial intelligence, are more efficient, very fast, and stable. For example, the biological swarm chasing method has an efficiency of around 12\% higher than the P\&O method [98].

The solar radiation and temperature can vary rapidly. In this case, the IC method is a better solution than the $\mathrm{P} \& \mathrm{O}$ method. The demerit of the IC method is the high time of computation. The intelligent algorithms can be a very promising MPPT method to solve the problem for rapid changes of temperature and solar radiation. The implementation of one method must take into consideration several factors, such as efficiency, cost, the simplicity or difficulty of algorithm implemented, hardware availability, and convergence time.

Problems for the MPPT appear in case of the photovoltaic panels which are partially shaded. This case is commonly met; for example, Eftichios and Gosumbonggot and Fujita show that $10 \%$ of the energy is lost because over $41 \%$ from panels which are mounted on roofs in Germany are affected by shading $[99,100]$. Another study shows that not detecting the maximum power leads to loss of $70 \%$ from the energy produced by PV systems [101]. 
There are multiple local maximum power values for shading cases and only one global maximum in normal case, without shading. Therefore, in shading cases, it is very important to determine the correct global maximum power. The conventional MPPT algorithms, such as constant voltage or short circuit current method, cannot detect the changes determined by shading or find the maximum power. Mohapatra et al. affirm that an accurate mathematical model is not available for shading conditions [89]. The correct global maximum power in shading conditions can be obtained using the new methods based on artificial intelligence or improved conventional methods such as perturbation, observation, or incremental conductance.

The improvement of consecrated MPPT leads to their aim fulfillment, but some issues appear as the tracking time is high [100]; results are good for short time, but results for long time are not presented [102]; the oscillation problem is still present when the system operates in rapid solar radiation changes and temperature variation [103-105]; the electronic circuit becomes increasingly complex due to additional control circuit, switches, and sensors, which eventually lead to cost increase. The methods which use artificial intelligence present almost the same issues in terms of complexity and cost implementation, but they can reduce the computational time due to increased speed and the accuracy. These are reached using improved PSO (particle swarm optimization) or hybrid bioinspired algorithms [106, 107], the oscillation also reducing. The premature convergence is a problem for the bioinspired algorithms. Mirjalili et al. proposed the salp swarm algorithm (SSA) which uses a control parameter and assures the convergence through the adaptive mechanism [108]. Wan et al. improved the performance of the SSA algorithm using the grey wolf optimization algorithm in order to provide a better leader structure but which keeps the adaptive mechanism [109]. They compare the results in terms of time convergence and maximum power of the PVs obtained for one consecrated method $\mathrm{P} \& \mathrm{O}$, and three algorithms PSO, SSA, and SSA-GWO. The consecrated method P\&O gives better results for the uniform irradiance case from the time convergence point of view (0.48s) than PSO (0.72s) and SSA $(0.58 \mathrm{~s})$ algorithms, but not for SSA-GWO (0.46 s) algorithm [109]. The maximum power determined through $\mathrm{P} \& \mathrm{O}$ is the lowest one due to the oscillations. In the case of one pattern with three local maximum points, the $\mathrm{P} \& \mathrm{O}$ determined the global maximum very fast in comparison with the other three ones, but the accuracy is the lowest. Thus, the time for the $\mathrm{P} \& \mathrm{O}$ is 0.15 while for SSA-GWO it is $0.53 \mathrm{~s}$, but the $P_{\max }$ is $34.64 \mathrm{~W}$ for $\mathrm{P} \& \mathrm{O}$ and $44.55 \mathrm{~W}$ for SSA-GWO [109]. By using bioinspired algorithms or the hybrid algorithms, the power fluctuations are reduced, the global maximum power point is rapidly but accurately determined, and they can be successfully used for partial shading and for rapid changes in irradiance.

\section{Conflicts of Interest}

The authors declare that they have no conflicts of interest. The authors are employed at Transilvania University of Brasov.

\section{References}

[1] March 2019, https://www.iea.org/weo2018/electricity/.

[2] J. L. Sawin, K. Seyboth, and F. Sverrisson, Renewables 2018 Global Status Report, REN21 Secretariat, Paris, France, 2018, March 2019, http://www.ren21.net/wp-content/ uploads/2018/06/17-8652_GSR2018_FullReport_web_-1 .pdf.

[3] M. A. Green, Y. Hishikawa, E. D. Dunlop et al., "Solar cell efficiency tables (version 53)," Progress in Photovoltaics: Research and Applications, vol. 27, no. 1, pp. 3-12, 2019.

[4] K. Yoshikawa, H. Kawasaki, W. Yoshida et al., "Silicon heterojunction solar cell with interdigitated back contacts for a photoconversion efficiency over 26\%," Nature Energy, vol. 2, no. 5, article 17032, 2017.

[5] T. Matsui, H. Sai, T. Suezaki et al., "Development of highly stable and efficient amorphous silicon based solar cells," in Proc. 28th European Photovoltaic Solar Energy Conference, pp. 2213-2217, Paris, France, September 2013.

[6] B. M. Kayes, H. Nie, R. Twist et al., " $27.6 \%$ conversion efficiency, a new record for single-junction solar cells under 1 sun illumination," in 2011 37th IEEE Photovoltaic Specialists Conference, Seattle, WA, USA, June 2011.

[7] J. L. Wu, Y. Hirai, T. Kato, H. Sugimoto, and V. Bermudez, "New world record efficiency up to $22.9 \%$ for Cu (In,Ga) (Se,S)2 thin-film solar cells," in 7th World Conference on Photovoltaic Energy Conversion (WCPEC-7), Waikoloa, HI, USA, June 2018.

[8] W. S. Yang, J. H. Noh, N. J. Jeon et al., "Solar cells. Highperformance photovoltaic perovskite layers fabricated through intramolecular exchange," Science, vol. 348, no. 6240, pp. 12341237, 2015.

[9] First Solar Press Release, First Solar Builds the Highest Efficiency Thin Film PV Cell on Record, 2014.

[10] K. Sasaki, T. Agui, K. Nakaido, N. Takahashi, R. Onitsuka, and T. TakamotoProceedings, 9th International Conference on Concentrating Photovoltaics Systems, Miyazaki, Japan, 2013.

[11] J. S. Cashmore, M. Apolloni, A. Braga et al., "Improved conversion efficiencies of thin-film silicon tandem (MICRO$\mathrm{MORPH}^{\mathrm{TM}}$ ) photovoltaic modules," Solar Energy Materials and Solar Cells, vol. 144, pp. 84-95, 2016.

[12] P. J. Verlinden, Will we have $>22 \%$ efficient multi-crystalline silicon solar cells?, PVSEC 26, Singapore, 2016.

[13] H. Sugimoto, "High efficiency and large volume production of CIS-based modules," in 2014 IEEE 40th Photovoltaic Specialist Conference (PVSC), Denver, CO, USA, June 2014.

[14] “Toshiba news," September 2017, https://www.toshiba.co.jp/ rdc/rd/detail_e/e1709_02.html.

[15] First Solar Press Release, First solar achieves world record 18.6\% thin film module conversion efficiency, 2015.

[16] T. Takamoto, H. Washio, and H. Juso, "Application of InGaP/GaAs/InGaAs triple junction solar cells to space use and concentrator photovoltaic," in 2014 IEEE 40th Photovoltaic Specialist Conference (PVSC), Denver, CO, USA, June 2014.

[17] https://global.sunpower.com/solar-panel-products/ sunpower-maxeon-solar-panels.

[18] S. Yilmaz, H. Riza Ozcalik, O. Dogmus, F. Dincer, O. Akgol, and M. Karaaslan, "Design of two axes sun tracking controller 
with analytically solar radiation calculations," Renewable and Sustainable Energy Reviews, vol. 43, pp. 997-1005, 2015.

[19] R. Singh, S. Kumar, A. Gehlot, and R. Pachauri, “An imperative role of sun trackers in photovoltaic technology: a review," Renewable and Sustainable Energy Reviews, vol. 82, pp. 32633278, 2018.

[20] W. Nsengiyumva, S. G. Chen, L. Hu, and X. Chen, "Recent advancements and challenges in Solar Tracking Systems (STS): a review," Renewable and Sustainable Energy Reviews, vol. 81, pp. 250-279, 2018.

[21] D. T. Cotfas and P. A. Cotfas, "A simple method to increase the amount of energy produced by the photovoltaic panels," International Journal of Photoenergy, vol. 2014, Article ID 901581, 6 pages, 2014.

[22] L. T. Kostic, Z. T. Pavlovic, and S. M. Krasic, "The effect of four flat plate reflectors on light energy-harvesting system characteristics," Facta Universitatis - Series: Physics, Chemistry and Technology, vol. 13, no. 3, pp. 171-180, 2015.

[23] K. Shanks, S. Senthilarasu, and T. K. Mallick, "Optics for concentrating photovoltaics: trends, limits and opportunities for materials and design," Renewable and Sustainable Energy Reviews, vol. 60, pp. 394-407, 2016.

[24] D. T. Cotfas, P. A. Cotfas, and O. M. Machidon, "Study of temperature coefficients for parameters of photovoltaic cells," International Journal of Photoenergy, vol. 2018, Article ID 5945602, 12 pages, 2018.

[25] L. Idoko, O. Anaya-Lara, and A. McDonald, "Enhancing PV modules efficiency and power output using multi-concept cooling technique," Energy Reports, vol. 4, pp. 357-369, 2018.

[26] D. T. Cotfas, P. A. Cotfas, D. I. Floroian, and L. Floroian, "Accelerated life test for photovoltaic cells using concentrated light," International Journal of Photoenergy, vol. 2016, Article ID 9825683, 7 pages, 2016.

[27] G. C. Lazaroiu, M. Longo, M. Roscia, and M. Pagano, "Comparative analysis of fixed and sun tracking low power PV systems considering energy consumption," Energy Conversion and Management, vol. 92, pp. 143-148, 2015.

[28] A. Al-Mohamad, "Efficiency improvements of photo-voltaic panels using a Sun-tracking system," Applied Energy, vol. 79, no. 3, pp. 345-354, 2004.

[29] G. Chicco, J. Schlabbach, and F. Spertino, "Performance of grid-connected photovoltaic systems in fixed and suntracking configurations," in 2007 IEEE Lausanne Power Tech, pp. 677-682, Lausanne, Switzerland, July 2007.

[30] I. Sefa, M. Demirtas, and İ. Çolak, "Application of one-axis sun tracking system," Energy Conversion and Management, vol. 50, no. 11, pp. 2709-2718, 2009.

[31] M. J. Clifford and D. Eastwood, "Design of a novel passive solar tracker," Solar Energy, vol. 77, no. 3, pp. 269-280, 2004.

[32] B. J. Huang and F. S. Sun, "Feasibility study of one axis three positions tracking solar PV with low concentration ratio reflector," Energy Conversion and Management, vol. 48, no. 4, pp. 1273-1280, 2007.

[33] C. Sungur, "Multi-axes sun-tracking system with PLC control for photovoltaic panels in Turkey," Renewable Energy, vol. 34, no. 4, pp. 1119-1125, 2009.

[34] J. F. Lee, N. A. Rahim, and Y. A. al-Turki, "Performance of dual-axis solar tracker versus static solar system by segmented clearness index in Malaysia," International Journal of Photoenergy, vol. 2013, Article ID 820714, 13 pages, 2013.
[35] H. Fathabadi, "Novel high accurate sensorless dual-axis solar tracking system controlled by maximum power point tracking unit of photovoltaic systems," Applied Energy, vol. 173, pp. 448-459, 2016.

[36] H. Fathabadi, "Novel high efficient offline sensorless dualaxis solar tracker for using in photovoltaic systems and solar concentrators," Renewable Energy, vol. 95, pp. 485494, 2016.

[37] M. Badea, A. S. Moraru, I. Visa, G. B. Burduhos, and M. Comsit, "Command-control-monitoring of a dual-axis tracking photovoltaic platform," in 7th IFAC Conference on Manufacturing Modelling, Management, and Control International Federation of Automatic Control, Saint Petersburg, Russia, June 2013.

[38] D. T. Cotfas, P. Cotfas, S. Kaplanis, D. Ursutiu, and C. Samoila, "Sun tracker system vs fixed system," Bulletin of the Transilvania University of Brasov Series III: Mathematics, Informatics, Physics, vol. 1, no. 50, pp. 545-552, 2008.

[39] D. T. Cotfas, S. Kaplanis, P. A. Cotfas, D. Ursutiu, and C. Samoila, "A new albedometer based on solar cells," in Proc. World Renewable Energy Congress X, A. Sayigh, Ed., Glasgow, 2008.

[40] R. V. Meyta and F. V. Savrasov, "To study the influence of snow cover on the power generated by photovoltaic modules," IOP Conference Series: Materials Science and Engineering, vol. 81, article 012110, 2015.

[41] T. C. R. Russell, R. Saive, A. Augusto, S. G. Bowden, and H. A. Atwater, "The influence of spectral albedo on bifacial solar cells: a theoretical and experimental study," IEEE Journal of Photovoltaics, vol. 7, no. 6, pp. 1611-1618, 2017.

[42] C. E. Valdivia, C. T. Li, A. Russell et al., "Bifacial photovoltaic module energy yield calculation and analysis," in 2017 IEEE 44th Photovoltaic Specialist Conference (PVSC), Washington, DC, USA, June 2017.

[43] M. Chiodetti, A. Lindsay, P. Dupeyrat et al., "PV bifacial yield simulation with a variable albedo model," in 32nd European Photovoltaic Solar Energy Conference and Exhibition, Munich, Germany, 2016.

[44] R. Arshad, S. Tariq, M. U. Niaz, and M. Jamil, "Improvement in solar panel efficiency using solar concentration by simple mirrors and by cooling," in 2014 International Conference on Robotics and Emerging Allied Technologies in Engineering (iCREATE), Islamabad, Pakistan, April 2014.

[45] W. A. M. Al-Shohani, R. Al-Dadah, S. Mahmoud, and A. Algareu, "Optimum design of V-trough concentrator for photovoltaic applications," Solar Energy, vol. 140, pp. 241254, 2016.

[46] C. S. Solanki, C. S. Sangani, D. Gunashekar, and G. Antony, "Enhanced heat dissipation of V-trough PV modules for better performance," Solar Energy Materials and Solar Cells, vol. 92, no. 12, pp. 1634-1638, 2008.

[47] S. Maiti, S. Banerjee, K. Vyas, P. Patel, and P. K. Ghosh, "Self regulation of photovoltaic module temperature in $\mathrm{V}$-trough using a metal-wax composite phase change matrix," Solar Energy, vol. 85, no. 9, pp. 1805-1816, 2011.

[48] M. E. Ya'acob, H. Hizam, H. Abdul Rahman, W. Z. Wan Omar, M. T. Htay, and A. H. M. A. Rahim, "A simple approach in estimating the effectiveness of adapting mirror concentrator and tracking mechanism for PV arrays in the tropics," International Journal of Photoenergy, vol. 2014, Article ID 341863, 7 pages, 2014. 
[49] J. Hu and T. Yachi, "Photovoltaic systems with solar tracking mirrors," in 2013 International Conference on Renewable Energy Research and Applications (ICRERA), Madrid, Spain, October 2013.

[50] O. K. Ahmed and S. M. Bawa, "Reflective mirrors effect on the performance of the hybrid PV/thermal water collector," Energy for Sustainable Development, vol. 43, pp. 235-246, 2018.

[51] G. M. Tina and P. F. Scandura, "Case study of a grid connected with a battery photovoltaic system: V-trough concentration vs. single-axis tracking," Energy Conversion and Management, vol. 64, pp. 569-578, 2012.

[52] H. Singh, M. Sabry, and D. A. G. Redpath, "Experimental investigations into low concentrating line axis solar concentrators for CPV applications," Solar Energy, vol. 136, pp. 421-427, 2016.

[53] Z. Mathys and P. J. Burchill, "Influence of location on the weathering of acrylic sheet materials," Polymer Degradation and Stability, vol. 55, no. 1, pp. 45-54, 1997.

[54] F. E. Sahin and M. Yllmaz, "High concentration photovoltaics (HCPV) with diffractive secondary optical elements," Photonics, vol. 6, no. 2, p. 68, 2019.

[55] F. Languy, K. Fleury, C. Lenaerts et al., "Flat Fresnel doublets made of PMMA and PC: combining low cost production and very high concentration ratio for CPV," Optics Express, vol. 19, Supplement 3, pp. A280-A294, 2011.

[56] G. Zhou, J. He, and L. Xu, "Antifogging antireflective coatings on Fresnel lenses by integrating solid and mesoporous silica nanoparticles," Microporous and Mesoporous Materials, vol. 176, pp. 41-47, 2013.

[57] A. Akisawa, M. Hiramatsu, and K. Ozaki, "Design of domeshaped non-imaging Fresnel lenses taking chromatic aberration into account," Solar Energy, vol. 86, no. 3, pp. 877-885, 2012.

[58] M. Benghanem, A. A. Al-Mashraqi, and K. O. Daffallah, "Performance of solar cells using thermoelectric module in hot sites," Renewable Energy, vol. 89, pp. 51-59, 2016.

[59] Z. A. Haidar, J. Orfi, and Z. Kaneesamkandi, "Experimental investigation of evaporative cooling for enhancing photovoltaic panels efficiency," Results in Physics, vol. 11, pp. 690-697, 2018.

[60] L. Mei, D. Infield, U. Eicker, and V. Fux, "Thermal modelling of a building with an integrated ventilated PV façade," Energy and Buildings, vol. 35, no. 6, pp. 605-617, 2003.

[61] D. Sato and N. Yamada, "Review of photovoltaic module cooling methods and performance evaluation of the radiative cooling method," Renewable and Sustainable Energy Reviews, vol. 104, pp. 151-166, 2019.

[62] H. G. Teo, P. S. Lee, and M. N. A. Hawlader, "An active cooling system for photovoltaic modules," Applied Energy, vol. 90, no. 1, pp. 309-315, 2012.

[63] R. Mazón-Hernández, J. R. García-Cascales, F. Vera-García, A. S. Káiser, and B. Zamora, "Improving the electrical parameters of a photovoltaic panel by means of an induced or forced air stream," International Journal of Photoenergy, vol. 2013, Article ID 830968, 10 pages, 2013.

[64] W. He, Y. Zhang, and J. Ji, "Comparative experiment study on photovoltaic and thermal solar system under natural circulation of water," Applied Thermal Engineering, vol. 31, no. 16, pp. 3369-3376, 2011.

[65] S. S. Joshi and A. S. Dhoble, "Photovoltaic -thermal systems (PVT): technology review and future trends," Renewable and Sustainable Energy Reviews, vol. 92, pp. 848-882, 2018.
[66] D. Yang and H. Yin, "Energy conversion efficiency of a novel hybrid solar system for photovoltaic, thermoelectric and heat utilization," IEEE Transactions on Energy Conversion, vol. 26, no. 2, pp. 662-670, 2011.

[67] N. Xu, J. Ji, W. Sun, W. Huang, J. Li, and Z. Jin, "Numerical simulation and experimental validation of a high concentration photovoltaic/thermal module based on point-focus Fresnel lens," Applied Energy, vol. 168, pp. 269-281, 2016.

[68] S. Krauter, "Increased electrical yield via water flow over the front of photovoltaic panels," Solar Energy Materials and Solar Cells, vol. 82, no. 1-2, pp. 131-137, 2004.

[69] K. A. Moharram, M. S. Abd-Elhady, H. A. Kandil, and H. elSherif, "Enhancing the performance of photovoltaic panels by water cooling," Ain Shams Engineering Journal, vol. 4, no. 4, pp. 869-877, 2013.

[70] M. Abdolzadeh and M. Ameri, "Improving the effectiveness of a photovoltaic water pumping system by spraying water over the front of photovoltaic cells," Renewable Energy, vol. 34, no. 1, pp. 91-96, 2009.

[71] M. Rosa-Clot, P. Rosa-Clot, G. M. Tina, and P. F. Scandura, "Submerged photovoltaic solar panel: SP2," Renewable Energy, vol. 35, no. 8, pp. 1862-1865, 2010.

[72] R. Cazzaniga, M. Rosa-Clot, P. Rosa-Clot, and G. M. Tina, "Floating tracking cooling concentrating (FTCC) systems," in 2012 38th IEEE Photovoltaic Specialists Conference, pp. 514-517, Austin, TX, USA, June 2012.

[73] E. M. do Sacramento, P. C. M. Carvalho, J. C. de Araújo, D. B. Riffel, R. M. da Cruz Corrêa, and J. S. P. Neto, "Scenarios for use of floating photovoltaic plants in Brazilian reservoirs," IET Renewable Power Generation, vol. 9, no. 8, pp. 10191024, 2015.

[74] N. Karami and M. Rahimi, "Heat transfer enhancement in a hybrid microchannel-photovoltaic cell using Boehmite nanofluid," International Communications in Heat and Mass Transfer, vol. 55, pp. 45-52, 2014.

[75] Z. Rostami, M. Rahimi, and N. Azimi, "Using high-frequency ultrasound waves and nanofluid for increasing the efficiency and cooling performance of a PV module," Energy Conversion and Management, vol. 160, pp. 141-149, 2018.

[76] H. A. Hussien, M. Hasanuzzaman, A. H. Noman, and A. R. Abdulmunem, "Enhance photovoltaic/thermal system performance by using nanofluid," in 3rd IET International Conference on Clean Energy and Technology (CEAT) 2014, Kuching, Malaysia, November 2014.

[77] A. K. Suresh, S. Khurana, G. Nandan, G. Dwivedi, and S. Kumar, "Role on nanofluids in cooling solar photovoltaic cell to enhance overall efficiency," Materials Today: Proceedings, vol. 5, no. 9, pp. 20614-20620, 2018.

[78] H. M. S. Bahaidarah, A. A. B. Baloch, and P. Gandhidasan, "Uniform cooling of photovoltaic panels: a review," Renewable and Sustainable Energy Reviews, vol. 57, pp. 15201544, 2016.

[79] A. Hasan, S. J. McCormack, M. J. Huang, and B. Norton, "Evaluation of phase change materials for thermal regulation enhancement of building integrated photovoltaics," Solar Energy, vol. 84, no. 9, pp. 1601-1612, 2010.

[80] P. H. Biwole, P. Eclache, and F. Kuznik, "Phase-change materials to improve solar panel's performance," Energy and Buildings, vol. 62, pp. 59-67, 2013.

[81] Y. S. Indartono, A. Suwono, and F. Y. Pratama, "Improving photovoltaics performance by using yellow petroleum jelly 
as phase change material," International Journal of LowCarbon Technologies, vol. 11, no. 3, pp. 333-337, 2014.

[82] A. Hasan, S. J. McCormack, M. J. Huang, and B. Norton, "Energy and cost saving of a photovoltaic-phase change materials (PV-PCM) system through temperature regulation and performance enhancement of Photovoltaics," Energies, vol. 7, no. 3, pp. 1318-1331, 2014.

[83] A. H. A. Al-Waeli, K. Sopian, M. T. Chaichan et al., "Evaluation of the nanofluid and nano-PCM based photovoltaic thermal (PVT) system: an experimental study," Energy Conversion and Management, vol. 151, pp. 693-708, 2017.

[84] M. Sardarabadi, M. Passandideh-Fard, M. J. Maghrebi, and M. Ghazikhani, "Experimental study of using both $\mathrm{ZnO} /$ water nanofluid and phase change material (PCM) in photovoltaic thermal systems," Solar Energy Materials \& Solar Modules, vol. 161, pp. 62-69, 2017.

[85] D. T. Cotfas, P. A. Cotfas, D. Ciobanu, and O. M. Machidon, "Characterization of photovoltaic-thermoelectric-solar collector hybrid systems in natural sunlight conditions," Journal of Energy Engineering, vol. 143, no. 6, article 04017055, 2017.

[86] S. Mahmoudinezhad, S. Ahmadi Atouei, P. A. Cotfas, D. T. Cotfas, L. A. Rosendahl, and A. Rezania, "Experimental and numerical study on the transient behavior of multi-junction solar cell-thermoelectric generator hybrid system," Energy Conversion and Management, vol. 184, pp. 448-455, 2019.

[87] T. H. Kil, S. Kim, D. H. Jeong et al., "A highly-efficient, concentrating-photovoltaic/thermoelectric hybrid generator," Nano Energy, vol. 37, pp. 242-247, 2017.

[88] N. Karami, N. Moubayed, and R. Outbib, "General review and classification of different MPPT techniques," Renewable and Sustainable Energy Reviews, vol. 68, pp. 1-18, 2017.

[89] A. Mohapatra, B. Nayak, P. Das, and K. B. Mohanty, "A review on MPPT techniques of PV system under partial shading condition," Renewable and Sustainable Energy Reviews, vol. 80, pp. 854-867, 2017.

[90] J. Hahm, J. Baek, H. Kang, H. Lee, and M. Park, "Matlabbased modeling and simulations to study the performance of different MPPT techniques used for photovoltaic systems under partially shaded conditions," International Journal of Photoenergy, vol. 2015, Article ID 979267, 10 pages, 2015.

[91] April 2019, http://re.jrc.ec.europa.eu/pvg_tools/en/tools .html.

[92] J. D. Rhodes, C. R. Upshaw, W. J. Cole, C. L. Holcomb, and M. E. Webber, "A multi-objective assessment of the effect of solar PV array orientation and tilt on energy production and system economics," Solar Energy, vol. 108, pp. 28-40, 2014.

[93] March 2019, https://www.steinel.de/en/lights-floodlights/ solar-lights/xsolar-l-s-silver.html.

[94] G. Quesada, L. Guillon, D. R. Rousse, M. Mehrtash, Y. Dutil, and P. L. Paradis, "Tracking strategy for photovoltaic solar systems in high latitudes," Energy Conversion and Management, vol. 103, pp. 147-156, 2015.

[95] B. G. Burduhos, I. Visa, A. Duta, and M. Neagoe, "Analysis of the conversion efficiency of five types of photovoltaic modules during high relative humidity time periods," IEEE Journal of Photovoltaics, vol. 8, no. 6, pp. 1716-1724, 2018.

[96] H. M. S. Bahaidarah, "Experimental performance investigation of uniform and non-uniform cooling techniques for photovoltaic systems," in 2015 IEEE 42nd Photovoltaic Specialist Conference (PVSC), pp. 14-19, New Orleans, Louisiana, USA, June 2015.
[97] A. A. B. Baloch, H. M. S. Bahaidarah, P. Gandhidasan, and F. A. Al-Sulaiman, "Experimental and numerical performance analysis of a converging channel heat exchanger for PV cooling," Energy Conversion and Management, vol. 103, pp. 14-27, 2015.

[98] L.-R. Chen, C.-H. Tsai, Y.-L. Lin, and Y.-S. Lai, “A biological swarm chasing algorithm for tracking the PV maximum power point," IEEE Transactions on Energy Conversion, vol. 25, no. 2, pp. 484-493, 2010.

[99] E. Koutroulis and F. Blaabjerg, "A new technique for tracking the global maximum power point of PV arrays operating under partial-shading conditions," IEEE Journal of Photovoltaics, vol. 2, no. 2, pp. 184-190, 2012.

[100] J. Gosumbonggot and G. Fujita, "Partial shading detection and global maximum power point tracking algorithm for photovoltaic with the variation of irradiation and temperature," Energies, vol. 12, no. 2, p. 202, 2019.

[101] S. Daraban, D. Petreus, C. Morel, and M. Machmoum, "A novel global MPPT algorithm for distributed MPPT systems," in 2013 15th European Conference on Power Electronics and Applications (EPE), pp. 1-10, Lille, France, September 2013.

[102] L. Gao, R. A. Dougal, S. Liu, and A. P. Iotova, "Parallel-connected solar PV system to address partial and rapidly fluctuating shadow conditions," IEEE Transactions on Industrial Electronics, vol. 56, no. 5, pp. 1548-1556, 2009.

[103] A. Jubaer, "An enhanced adaptive P\&O MPPT for fast and efficient tracking under varying Environmental Conditions," IEEE Transactions on Industrial Electronics, vol. 9, no. 3, pp. 1487-1496, 2008.

[104] K. Ş. Parlak and H. Can, "A new MPPT method for PV array system under partially shaded conditions," in 2012 3rd IEEE International Symposium on Power Electronics for Distributed Generation Systems (PEDG), pp. 437-441, Aalborg, Denmark, June 2012.

[105] R. Alik, A. Jusoh, and N. A. Shukri, “An improved perturb and observe checking algorithm MPPT for photovoltaic system under partial shading condition," in 2015 IEEE Conference on Energy Conversion (CENCON), Johor Bahru, Malaysia, October 2015.

[106] K. Sundareswaran, S. Peddapati, and S. Palania, "MPPT of PV systems under partial shaded conditions through a colony of flashing fireflies," IEEE Transactions on Energy Conversion, vol. 29, no. 2, pp. 463-472, 2014.

[107] K. Sundareswaran, V. Vignesh kumar, and S. Palani, “Application of a combined particle swarm optimization and perturb and observe method for MPPT in PV systems under partial shading conditions," Renewable Energy, vol. 75, pp. 308-317, 2015.

[108] S. Mirjalili, A. H. Gandomi, S. Z. Mirjalili, S. Saremi, H. Faris, and S. M. Mirjalili, "Salp swarm algorithm: a bio-inspired optimizer for engineering design problems," Advances in Engineering Software, vol. 114, pp. 163-191, 2017.

[109] Y. Wan, M. Mao, L. Zhou, Q. Zhang, X. Xi, and C. Zheng, "A novel nature-inspired maximum power point tracking (MPPT) controller based on SSA-GWO algorithm for partially shaded photovoltaic systems," Electronics, vol. 8, no. 6, p. $680,2019$. 

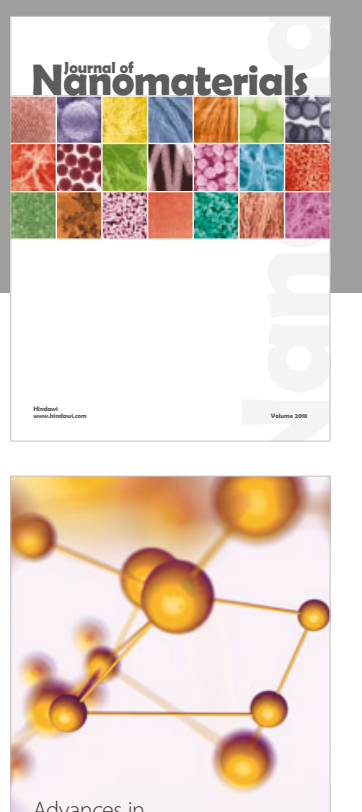

Physical Chemistry
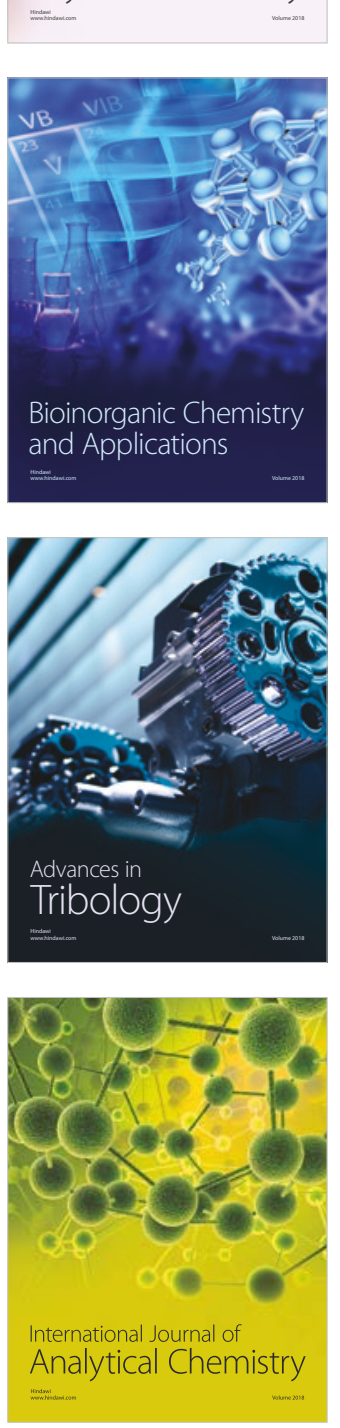

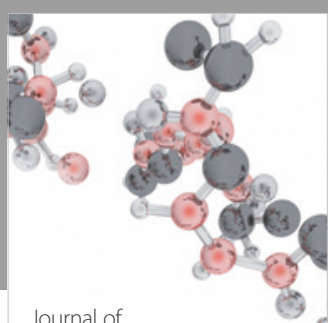

Analytical Methods

in Chemistry

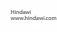

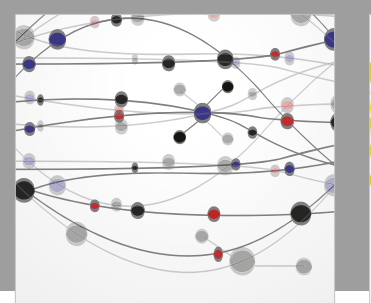

The Scientific World Journal

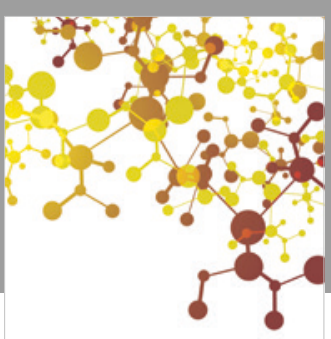

Journal of

Applied Chemistry
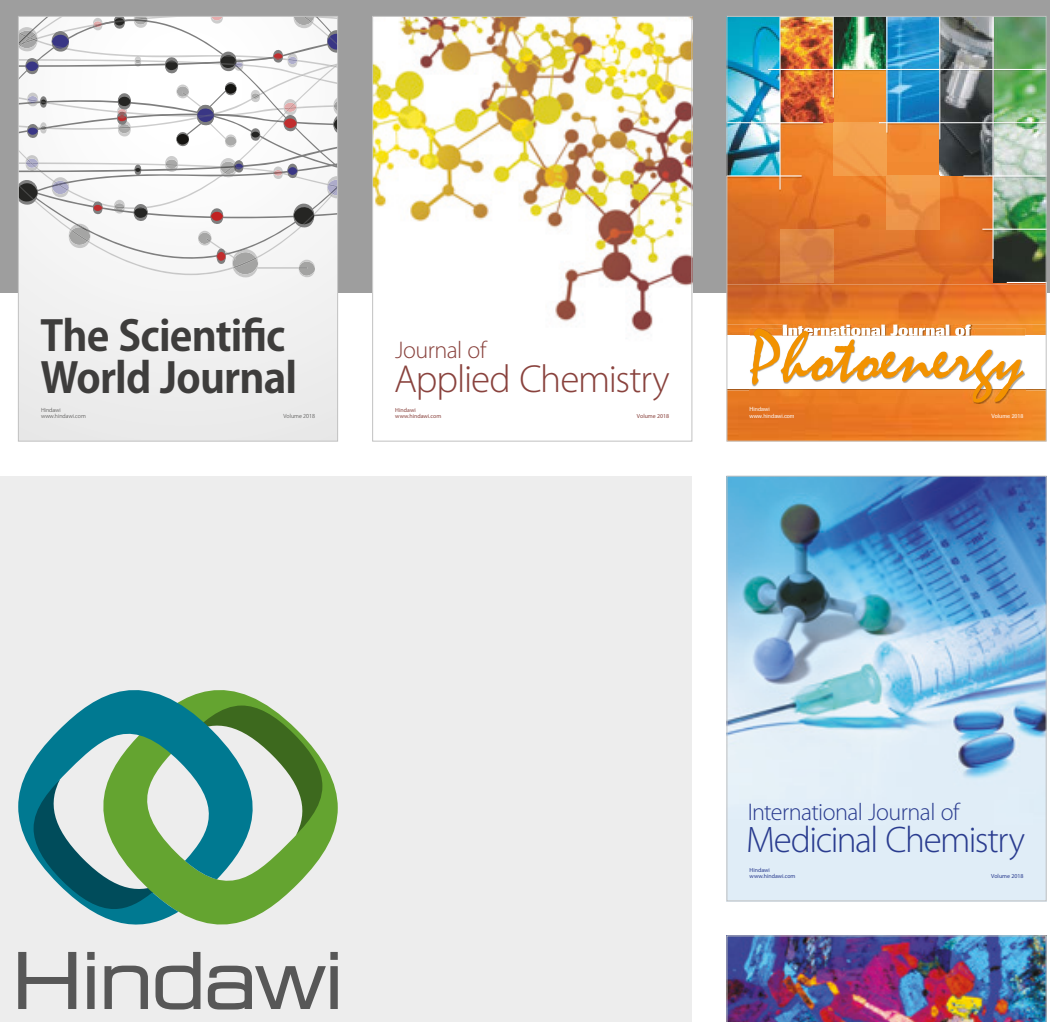

Submit your manuscripts at

www.hindawi.com
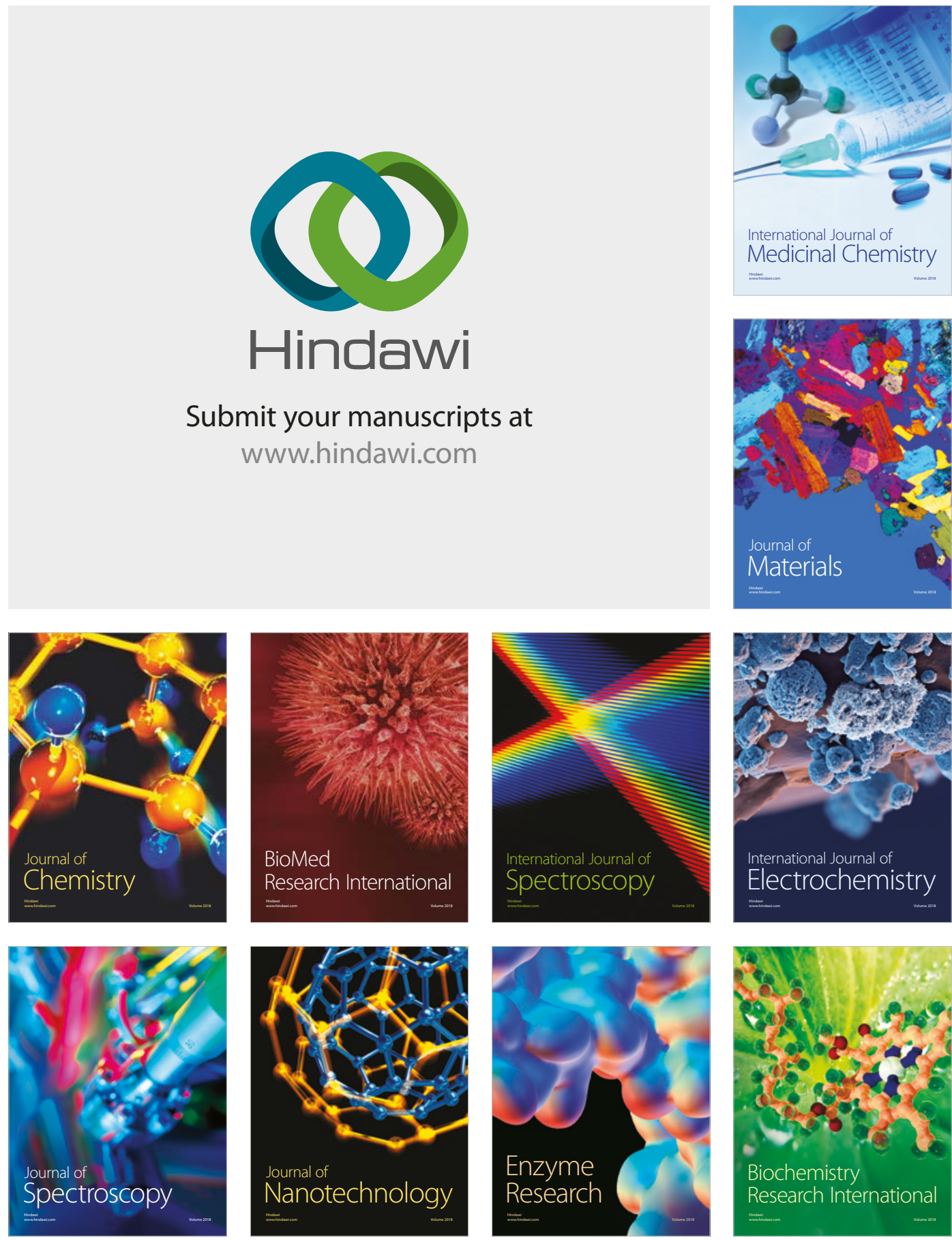
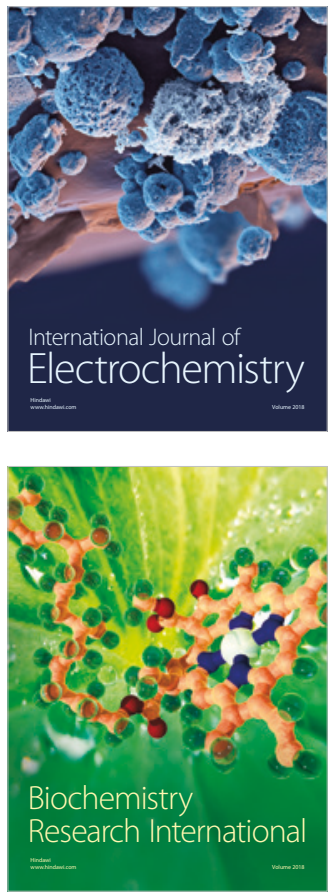